\title{
Article \\ Le Corbusier's Urban Planning as a Cultural Legacy. An Approach to the Case of Chandigarh
}

\author{
Juan-Andrés Rodríguez-Lora ${ }^{1}$, Ana Rosado ${ }^{2}\left(\mathbb{D}\right.$ and Daniel Navas-Carrillo ${ }^{1, *}$ (i) \\ 1 Heritage and Urban Territorial Development in Andalusia (HUM700), Higher Technical School of \\ Architecture, University of Seville, 41012 Seville, Spain; jrodriguez91@us.es \\ 2 Mertola's Archaeological Field (CAM), Centro de Estudos em Arqueologia, Artes e Ciências do \\ Património (CEAACP), 7750-353 Mértola, Portugal; ana.costa.rosado@gmail.com \\ * Correspondence: dnavas@us.es
}

check for updates

Citation: Rodríguez-Lora, J.-A.; Rosado, A.; Navas-Carrillo, D. Le Corbusier's Urban Planning as a Cultural Legacy. An Approach to the Case of Chandigarh. Designs 2021, 5 , 44. https://doi.org/10.3390/ designs5030044

Academic Editor: Ana M. T. Martins

Received: 14 June 2021

Accepted: 16 July 2021

Published: 21 July 2021

Publisher's Note: MDPI stays neutral with regard to jurisdictional claims in published maps and institutional affiliations.

Copyright: (c) 2021 by the authors. Licensee MDPI, Basel, Switzerland. This article is an open access article distributed under the terms and conditions of the Creative Commons Attribution (CC BY) license (https:// creativecommons.org/licenses/by/ $4.0 /)$.

\begin{abstract}
The uniqueness and importance of Le Corbusier's work were ratified by the recognition and inclusion of 17 of his projects as heritage legacy on UNESCO's (The United Nations Educational, Scientific and Cultural Organization) World Heritage List in 2016. Despite the disciplinary diversity of his entire career, it is his architectural work that enjoys the greatest levels of dissemination and recognition. Consequently, it is assumed that Le Corbusier's architectural work is more protected than its urban plans. This article aims to advance the recognition of the latter. To this end, it proposes a cartographic and documentary review of his projects, a specialized bibliographic review, as well as a review of national and international databases on his built work. Of 88 built works, at least 51 have some kind of heritage protection. In any case, less attention is paid to the urban dimension of his work. The city of Chandigarh presents a series of particularities, apart from being the only Corbusierian city built, which could raise the need for its safeguarding and recognition as a cultural legacy. 20th-century urban planning, and Chandigarh in particular, require the application of criteria complementary to those usually applied in heritage protection in object-based approaches.
\end{abstract}

Keywords: Chandigarh; contemporary heritage; Modern Movement; UNESCO; urban heritage; World Heritage List; 20th-century

\section{Introduction}

Le Corbusier's works are internationally renowned as a crucial part of 20th-century architecture, and they still influence architects today. The architect's legacy goes beyond the traditional fields of Architecture and Urbanism, and the scope and diversity of his artistic creations would be categorised under the concept of 'Synthesis of the Arts' [1] (p. 7). Le Corbusier's architectonic works would receive international recognition with their inclusion in UNESCO's 'World Heritage List' [2], thus consolidating and confirming their historical significance both along with other important 20th-century architecture figures and works, as well as in their own singularity.

Although Le Corbusier's works are, as stated, very diverse and covering different artistic fields, the bulk of attention his work has received relates to his architectonic production. Therefore, the scientific research regarding his urban projects is smaller than that dedicated to his architectonic works. Even if his city-scale projects would only be materialised in the city of Chandigarh (India), Le Corbusier conceived over twenty urban plans during his career, at different scales [3]. There is a larger knowledge of his architectonic work than, for instance, his urban plans, as there is also a more extensive diffusion of the former. That is true even in the diffusion promoted by the Fondation Le Corbusier [4]. This could translate into the hypothesis-which this article aims to prove-that there is a larger heritage recognition and protection of Le Corbusier's buildings than his urban-sphere projects. That would include urban fragments, which are nowadays considered heritage elements to be classified. 
Therefore, this article intends, through the listing of Le Corbusier's works classified under any heritage category, to help overcome the vision of single-building protection and advocate for recognising his urban scale works.

\section{Materials and Methods}

The research proposes a progressive approach to the object of study from a primarily heritage approach. To this end, the work has been structured in two main phases ranging from the general: heritage recognition of the production of the Modern Movement, to the particular: evaluation of the cultural values of the case study, Chandigarh.

The paper begins by analysing the conceptual evolution of the notion of heritage since the second half of the last century. The aim is to contextualise the progressive recognition of 20th-century production as an emerging heritage to be safeguarded. In addition to the relevant bibliographical review, the research has consulted the principal charters and guidelines issued by the leading international heritage organisations (UNESCO, ICOMOS, GETTY) and, in particular, those that work to preserve 20th-century architecture and urban planning (DOCOMOMO, ISC20C).

The starting point is the hypothesis that even today, 20th-century heritage is characterised by an objectual and architectural vision, to the detriment of the urban heritage dimension. Consequently, this first phase also seeks to identify keys that will enable significant progress in the heritagisation of 20th-century urban production. Thus, from the general framework, the representativeness of the 20th-century output has been analysed at the international level based on UNESCO's World Heritage List.

From a specific point of view, the article has sought to identify the degree of preservation afforded to Le Corbusier's built work. To this end, the information available at the Fondation Le Corbusier [5] has been taken as a reference, checking the heritage inventories and catalogues of the countries where his production is located: Argentina, Belgium, Brazil, France, Germany, India, Iraq, Japan, Russia, Switzerland, Tunisia, and the United States. In both cases, the study is based on an initial general overview which, given the initial hypothesis, is then specialised for those pieces with an urban dimension.

The second phase of the research focuses on the detailed analysis of the case study. Chandigarh was the only proposal built by Le Corbusier which, at the height of his professional maturity, synthesises many of the concepts present in his extensive urban production. Consequently, the first step has been to analyse the evolution of his theories summarised based on four urban models: Ville Contemporaine, Ville Radieuse, Industrial Linear City, and the 7V model. This approach has been carried out through a systematic bibliographical review and documentary analysis of his urban projects, inventoried by the Fondation Le Corbusier [5] and published, among other places, in Le Corbusier Plans [6]. From here, the original design and the current state were analysed in depth. Accordingly, it has been essential to consult urban aerial images.

Finally, the research identifies potentialities for the heritagisation of Chandigarh from three perspectives. Firstly, the article analyses the international, national, and local tutelage effort, assessing the role given to date to the urban dimension. Subsequently, it identifies the core urban values based on the previous analysis of the city and Le Corbusier's complete urban work. Lastly, it establishes the main criteria since articulating the value assessment necessary to advance in the recognition and preservation of Chandigarh as a significant example of twentieth-century urban planning.

\section{The Modern Movement as Heritage Legacy}

\subsection{The Relevance of Safeguarding the Modern Movement's Works}

This research approaches 20th-century architecture as a heritage object. A vision that could go against some of the modern principles [7] (p. 19), or the anti-monumental criticism of various modern authors [8] (p. 17). However, under current considerations and the evolution of the concept of heritage, Modern Movement works represent a challenge for society and agents involved in heritage in the 21st-century. 
The Modern Movement represents a period where architecture shows a clean language and a high level of experimentation, regarding both space and materials, which meant a rupture with several aspects of former architectural expressions. That is why Modern Architecture is characterised by a group of singular values that cannot be seen in earlier architectural phases.

Nonetheless, one should avoid the recurring misunderstanding that the Modern Movement, especially Le Corbusier, has cut ties with history and their past. Several investigations establish how Le Corbusier's work was influenced by and reflects a thorough study of the past.

Everything he learned and discovered in his travels to the East would transcend in his work [9]. In this sense, links to the Mughal tradition are found in his proposal for Chandigarh $[10,11]$ or the influence of the classical Greco-Latin antiquity is shown in some of his public spaces [12].

The main objective is the analysis of modern production. Historicist buildings tend to receive a greater social recognition than those of the 20th-century [13] (p. 82). Therefore, to allow for modern production to have more significant support in terms of its protection, it is important that research focuses on modern works. Hence, the present research has focused on the architecture and urbanism of the Modern Movement, a historical period whose beginning could be set in 1925. Nevertheless, it should not be seen as a fixed date, as several previous examples respond to modern premises. In this sense, Carlos Flores López [14] (p. 93) stresses that "1925 is the deadline, because around that time, even though the architecture that was still being built was similar to that of previous years, new ideas began to take shape, a new spirit of work was inaugurated among architects who had recently left the classrooms".

The research assumes the conceptual evolution undergone by the notion of Heritage throughout the 20th-century, overcoming its initial consideration of the monument as an isolated element. Moreover, it assumes the overcoming of historical value or antiquity as the main criterion on which to articulate protection. As Víctor Pérez Escolano [15] (p. 12) points out, "It is not a question of ageing, but of recognising the most valuable testimonies of the most dynamic fragment of 20th-century architecture".

Despite the evolution of the concept of Heritage, the intrinsic contemporary nature of Modern architecture and urbanism makes them an emerging heritage, and it means current weaker protection than older heritage objects. This contemporary nature, added to the singular architectonic characteristics of the period's works, create the necessity for new criteria to identify and list these objects. The new criteria should be complementary to those already used in heritage enhancement, which can often be hard to apply to Modern Movement works.

Records and inventories of Modern Movement works have had a key role in the process of heritage enhancement of this legacy, as they have shown the value of many of the listed works. Nevertheless, they are not effective in protecting the integrity of the works, as can be often seen in our geographic surroundings.

Excluding professionals of architecture, heritage, and others alike, the lack of acknowledgement of the heritage values of modern works is transversal to most society's spheres. As stated by Eduardo Mosquera Adell [16] (pp. 16-17) regarding the Sevillian building of "Cabo Persianas", its recognition as a heritage building is controversial even to the authorities in charge of the tutelary action.

However, it should be noted that there has now been a notable advance in these matters with the incorporation, by the competent public administrations, of these buildings into the different protection tools available to them. In this way, they have become part of the various protection catalogues in use by the different public administrations. Despite that effort, many are still under threat of vanishing as exemplified by the cases of the pharmaceutical laboratories Jorba (Miguel Fisac), Casa Guzmán in Madrid (Alejandro de la Sota) and, most emblematic, Robin Hood Gardens in London (Alison and Peter Smithson). 
These cases show how ensuring protection and enhancing these buildings' value is still fundamental today. Demolition is not the only danger faced by this contemporary heritage: significant modifications are carried out to adapt these buildings to the new requirements of the uses of today's society, at the expense of heritage values.

Finally, the study and recognition of this emerging heritage have been articulated based on considerations of isolated objects that respond to criteria of a traditional nature, without considering the city scale and the internal relationships that occur within it. For this reason, this research has sought to consider the urban and territorial scale as a support for this heritage, enabling its understanding as a whole, as well as highlighting the importance of the environment in the implementation of these buildings within the city.

\subsection{Track Record in the Recognition of 20th-Century Production}

The concept of heritage is a mental construction, it is in constant evolution and reinterpretation. Its understanding reflects the society that defined it at each historical stage. Hence, it is crucial to understand projects from the temporal context in which they were carried out.

Heritage has, in each period, encompassed different cultural assets: starting with tangible assets, ranging from monumental historic buildings to contemporary ones, and finally including intangible assets. This opening up has mainly taken place throughout the 20th-century and up to the present. The transformation is attested by the various international documents, declarations and charters [17] (p. 3). Consequently, the positioning of the agents involved in the heritage and the view of these elements have changed over time.

The review of these international publications shows the evolutionary trajectory of the concept of heritage and the final incorporation of contemporary heritage.

The first steps in the opening up of the concept of heritage and the overcoming of the eminently monumentalist 19th-century vision can be found in the Athens Charter for the Restoration of Historic Monuments of 1931 [18]. This document stands out for its assumption of the scalar overcoming of the monumental building on its own. In this sense, the recognition and protection of urban areas around monuments are of interest.

The conception of heritage as an international fact that goes beyond the vision of belonging uniquely to each state or country is reflected in the 1954 Hague Convention [19]. In addition to this, the concept of "cultural heritage" is mentioned and conceived, thus overcoming the historical-artistic vision prevailing up to that time.

A decade later, a profound reformulation of the concept of heritage took place in the Venice Charter of 1964 [20]. Through the recognition of popular architecture as heritage, the vision centred exclusively on monuments was finally overcome. This openness would make it possible to begin to recognise other architectures as part of the cultural heritage.

The progressive recognition of 20th-century architecture as heritage arose as a reaction to the loss of this architecture before the end of the century in which they were built.

Firstly, with the issue of the 1971 Prague Declaration [21], a document derived from the meeting of heritage experts from ICOMOS, 11 European countries, the UNESCO and the institutions of what was then Czechoslovakia. Besides being considered the first occasion to discuss contemporary monuments, the recognition of the lack of protection of contemporary heritage as a real problem at the international level is also noteworthy.

Another important milestone for the recognition of this heritage was the Eindhoven Declaration, which led to the founding of Docomomo in 1990 [22]. While the Prague Declaration focuses on buildings constructed during the 19th and 20th centuries, Docomomo focuses specifically on the production of the Modern Movement, from 1925 to 1965 in an early stage and currently extended to 1975.

Almost at the same time, in 1991, the Committee of Ministers of the European Union published Recommendation No. (91)13 [23], which expressed the concern of the European institutions regarding the lack of recognition and protection of contemporary architecture. Among other issues, it highlights the importance of this architecture as a symbol and legacy of the consolidation of relations between the member states. 
The lesser attention received by this heritage is reflected in global heritage lists, which show a clear imbalance. It was detected by UNESCO around 1994 [17]. To alleviate this situation, UNESCO developed specific programmes to correct the imbalance concerning 19th and 20th-century heritage, known as contemporary heritage. These actions led to the publication of a special issue in 2003 of the World Heritage Papers, volume five of which would be dedicated to this cultural heritage under the title 'Identification and Documentation of Modern Heritage' [24]. Annex A of this publication lists all the contemporary heritage included up to that time in the World Heritage List, comprising a total of 25 elements: 12 modern heritage properties (19th and 20th centuries) and 12 industrial heritage properties.

Another recent UNESCO action is the creation, alongside ICOMOS, of the International Scientific Committee on 20th Century Heritage (ISC20C). This body focuses on the architectural production of the entire 20th-century, accepting the heterogeneity of the works carried out during the last century. It led to the publication of the Madrid Document of 2011 [25]. This text is of obvious importance. It is the document that solves the absence of international doctrinal documents in relation to the criteria for the identification, conservation, intervention, and management of 20th-century heritage recognised by UNESCO.

The evolution in the concept of heritage is also evident in the recent trajectory of the Getty Conservation Institute [26], which developed specific programmes for the safeguarding of contemporary heritage, such as the Conserving Modern Architecture Initiative or its dissemination through training and publications [27].

\subsection{Modern Architecture and Cities Recognised as World Heritage Sites}

The UNESCO World Heritage List has been progressively enriched by the inclusion of works of the period analysed here. At present, in addition to the 17 works by Le Corbusier previously mentioned [2], other buildings with worldwide recognition were classified. The Rietveld Schröder House by Gerrit Thomas Rietveld was included on the list in 2000 [28]. Then, in 2001, the 'Tugendhat Villa in Brno by Mies van der Rohe [29]. The most recent inclusion in the list is akin to the case of Le Corbusier, as it meant the inclusion of a compendium of works by the same author. It is the case of 'The 20th-Century Architecture of Frank Lloyd Wright', which would enter the UNESCO list in 2019 (UNESCO, 2019) [30], with eight buildings.

It is also noteworthy the inclusion of the "Bauhaus and its Sites" in Weimar, Dessau and Bernau' [31], consisting of significant buildings drawn in Rationalism and Modern Movement languages, of which the Bauhaus building in Dessau and the teachers' houses are the best-known examples.

At a larger scale, the list includes two university campuses, both located in the Americas and conceived from modern precepts. These complexes recognised as cultural legacies were the "University City of Caracas" included in 2000 [32] and the "Central Campus of the University City of the National Autonomous University of Mexico" [33], seven years later.

Regarding the urban sphere, there are several cities built from scratch during the 20th-century. There is the case of the New Towns, mainly in The United Kingdom and The Netherlands, and, on a smaller scale, the agrarian colonisation villages in Spain and Portugal. Nonetheless, it is the cases of Brasilia (Brasil) and Chandigarh (India) the ones with higher international acclaim both due to their scale as capitals of country or states, as well as their experimental planning according to the principles of the Modern Movement.

Brasilia was planned by Lucio Costa, and its buildings were projected by Oscar Niemeyer. It was classified as UNESCO World Heritage in 1987 [34], only three decades after laying its foundation stone. Dismally, the Indian city planned by Le Corbusier, Pierre Jeanneret, Jane Drew and Maxwell Fry does not have, as of today, the same level of recognition. Instead of the classification of the whole city, only its Capitol ensemble-with buildings drawn by Le Corbusier-is listed. 
Thus, except for the Brazilian city, the modern ex novo city does not occupy notable levels of recognition by UNESCO, which focuses mainly on architectural elements as is evident in its own list. The exception would be some fragments of cities, such as social housing complexes in Berlin or the reconstruction of Le Havre in France [35] (p. 7).

Along with the aforementioned Le Havre, inscribed in 2005 as "the City Rebuilt by Auguste Perret" [36], one should add the inclusion of the "White City of Tel Aviv" on the World Heritage List in 2003, with a layout linked to modern organic urbanism designed by Patrick Geddes [37], as well as the entry in 2013 of Casablanca on the UNESCO Tentative Lists under the heading "Ville du XXème siècle, Carrefour d'influences" [38].

\section{Le Corbusier's Work as Heritage}

Of all the projects included in his Oeuvre Complète [39], only 88 were built. Of these, at least 51 works have been listed as heritage, based on the heritage legislation of the countries and/or regions where they were built (Table 1, Figure 1).

Table 1. Total number of construction sites and buildings that have been heritage listed by country.

\begin{tabular}{|c|c|c|c|}
\hline \multirow{2}{*}{ Country } & \multirow{2}{*}{ Total } & \multicolumn{2}{|c|}{ Heritage Listed Buildings } \\
\hline & & Num. & Building Denominations \\
\hline Argentina & 1 & 1 & Maison du Docteur Curutchet \\
\hline Belgium & 2 & 2 & Maison Guiette; Pavillon Philips \\
\hline Brazil & 1 & 0 & - \\
\hline France & 47 & 35 & $\begin{array}{l}\text { Château d'eau; Maison-Atelier Ozenfant; Villa Besnus; } \\
\text { Maisons La Roche-Jeanneret; Maisons } \\
\text { Lipchitz-Miestchaninoff; Maison Ternisien; Quartiers } \\
\text { Modernes Frugès; Lotissement de Lége; Maison Planeix; } \\
\text { Villa Cook; Villa Stein-de Monzie “Les terrasses"; Villa } \\
\text { Savoye et loge du jardinier; Villa de Madame H. de Mandrot; } \\
\text { Cité de Refuge; Pavillon Suisse; Immeuble Porte Molitor; } \\
\text { Unité d’habitation de Marseille; Usine Claude \& Duval; } \\
\text { Maison des pélerins; Chapelle Notre Dame du Haut; Le } \\
\text { Cabanon; Maison du gardien; Maisons Jaoul; Unite } \\
\text { d’habitation de Reze-les-Nantes; Aeroclub (Doncourt); } \\
\text { Couvent Sainte-Marie de la Tourette; Maison du Bresil; } \\
\text { Tombe de Le Corbusier; Unité d'babitation Briey en Forêt; } \\
\text { Stade de Firmin; Unité d’habitation de Firminy; Eglise } \\
\text { Saint-Pierre; Ecluse de Kembs-Niffer); Maison des Jeunes et } \\
\text { de la Culture }\end{array}$ \\
\hline Germany & 2 & 2 & Deux maisons du Weissenhof; Unité d'Habitation de Berlin \\
\hline India & 19 & 0 & - \\
\hline Iraq & 1 & 0 & - \\
\hline Japan & 1 & 1 & Musée National d'Art Occidental \\
\hline Russia & 1 & 0 & - \\
\hline Switzerland & 10 & 9 & $\begin{array}{l}\text { Villa Fallet; Villa Stotzer; Villa Jacquemet; Villa } \\
\text { Jeanneret-Perret; Villa Favre-Jacot; Villa Schwob; Villa Le Lac; } \\
\text { Immeuble Clarté; Pavillon d'exposition ZHLC (Centre Le } \\
\text { Corbusier) }\end{array}$ \\
\hline Tunisia & 1 & 0 & - \\
\hline $\begin{array}{l}\text { United } \\
\text { States }\end{array}$ & 2 & 1 & Carpenter Center for the Visual Arts \\
\hline Total & 88 & 51 & \\
\hline
\end{tabular}




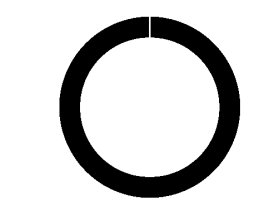

Argentina

1/1 (100\%) protected

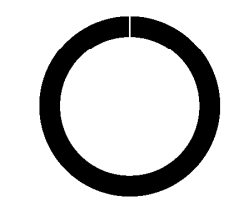

Germany

2/2 $(100 \%)$ protected

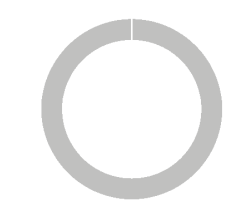

Russia

0/1 $(0 \%)$ protected

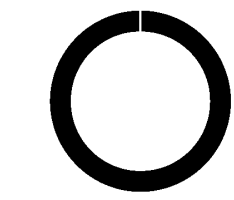

Belgium

$2 / 2(100 \%)$ protected

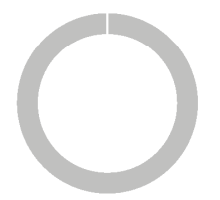

India

0/19 (0\%) protected

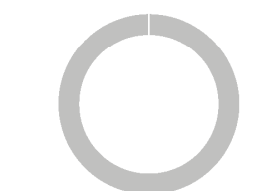

Iraq

0/1 $(0 \%)$ protected

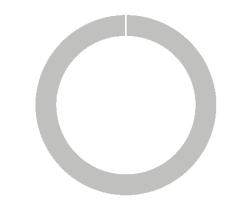

Tunisia

0/1 $(0 \%)$ protected

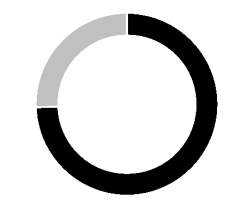

France

35/47 (74.47\%) protected

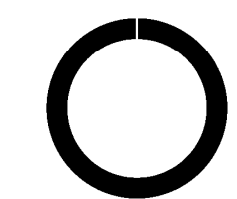

Japan

1/1 (100\%) protected

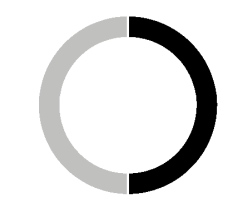

United States

$1 / 2(50 \%)$ protected

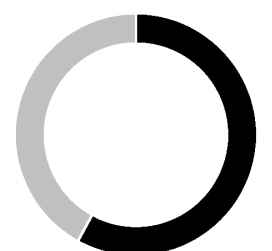

TOTAL

$51 / 88(57.95 \%)$ protected

Figure 1. Graphics with total number and percentage of construction sites and buildings that have been heritage listed by country. Source: Authors.

Of all of them, the cases of France and Switzerland are particularly noteworthy. Having a large part of Le Corbusier's built work on their soil, they have made significant progress in recognising and protecting his works. In the French case, 31 works have been declared Historic Monuments, and four others are registered in the Mérimée database [40]. In the Swiss case, 19 works are included in the Inventaire suisse des biens culturels d'importance nationale et régional [41]. It is surprising that none of the 19 buildings constructed in India is protected as a Protected Monument [42], especially in the case of Chandigarh. It is the only case in which properties included in the World Heritage Declaration do not enjoy national recognition at the same time, in addition to the fact that it is the only built city designed by Le Corbusier. This fact justifies its interest as a case study. Likewise noteworthy are several buildings in Ahmedabad, India. Currently, those have contrasting levels of conservation. 
The Ahmedabad Museum, which shares with the Chandigarh and Japan Museums its concept of unlimited growth, is currently abandoned and with a high level of deterioration (Figure 2). On the other hand, both Shodhan Villa and the Mill Owners' Association Building (Figure 3) have an adequate conservation and a remarkable current condition.
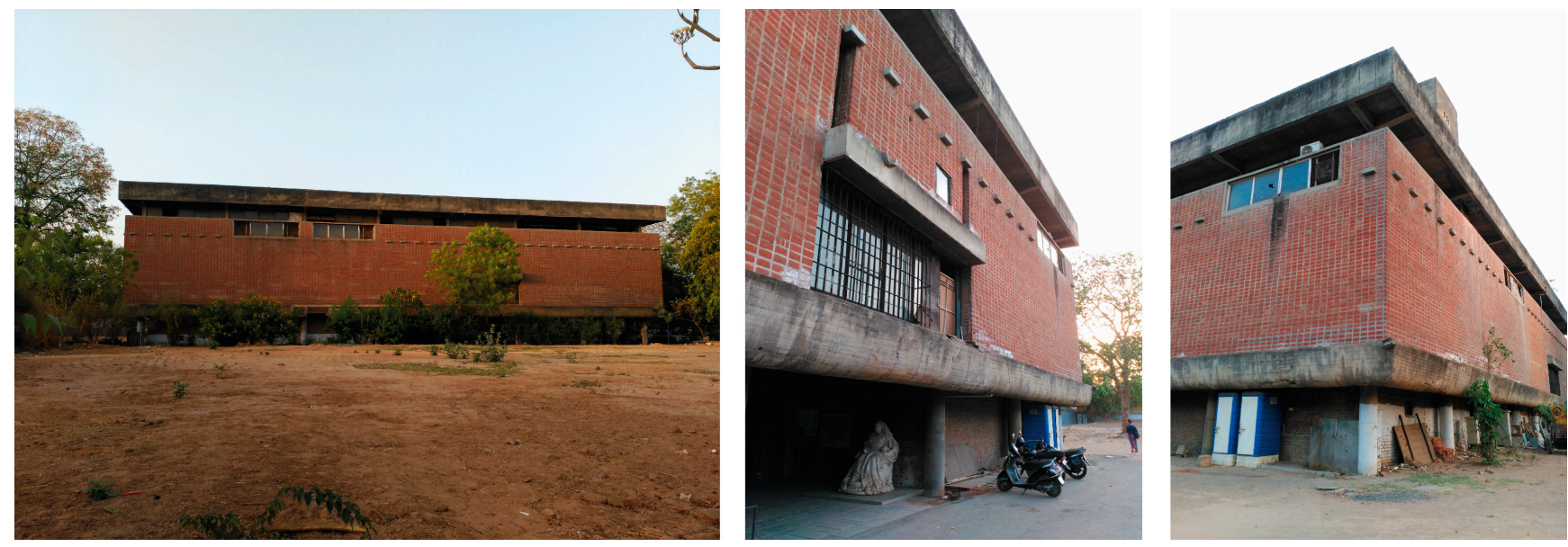

Figure 2. Ahmedabad Museum (India, built in 1951) abandoned and degraded. Source: Authors.
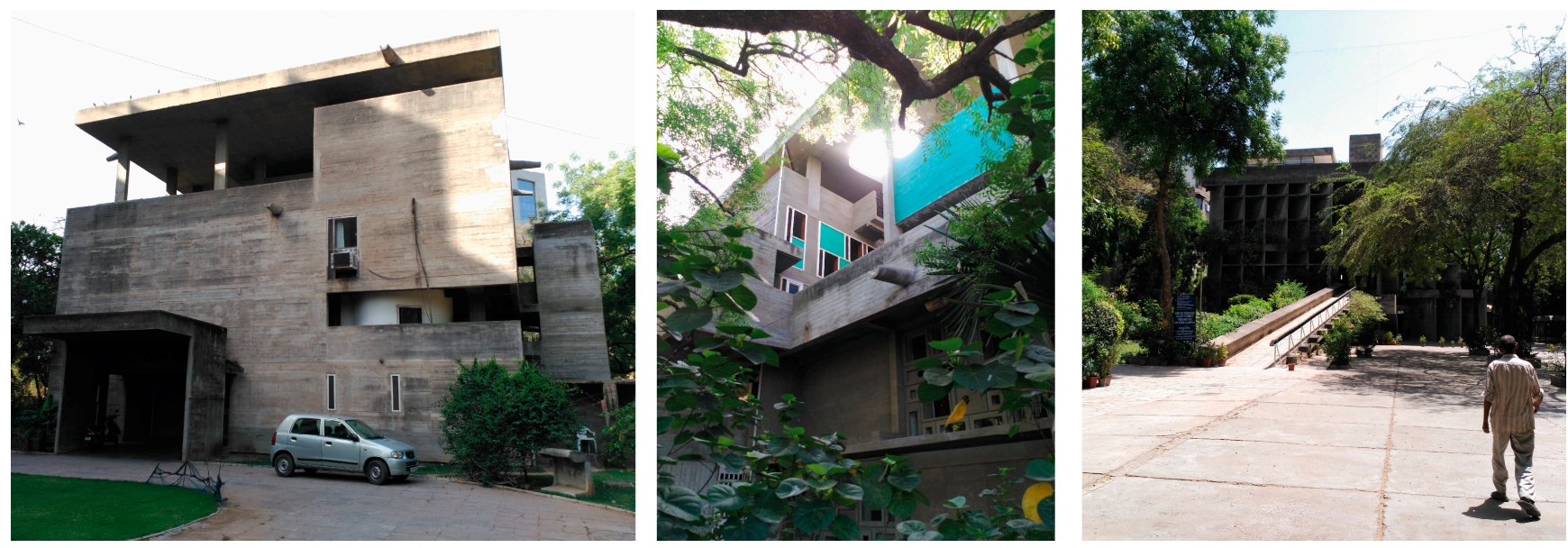

Figure 3. Villa Schodhan (left and centre) and Millowner's Association Building (right), both built in 1951 in Ahmedabad (India) and both in use but not protected. Source: Authors.

In addition, of the 37 non-listed buildings, eight were demolished, all of them in France: Maison du Tonkin; Maison Ternisien; Pavillon Nestlé; Villa Church; Pavillon d'aviation S.T.A.R.; Appartement de M. Charles de Beistegui; Pavillon des Temps Nouveau; Pavillon de L'Esprit Nouveau. In 1977, a replica of the latter building was built in Bologna (Italy). Additionally, the cinema La Scala (La Chaux-de-Fonds, Switzerland) was destroyed by fire in 1971, and only part of the original façade was rebuilt.

In any case, the above table shows that the recognition and protection of Le Corbusier's work are focused on his architectural pieces. The only works that have a certain urban dimension due to their status as residential developments are the Quartiers Modernes Frugès and the Lotissement de Lége. We should add to the list the two dwellings built by Le Corbusier in Stuttgart. Built as part of the DIE Wohnung exhibition, they were integrated into the overall development of the Weissenhofsiedlung. They were the first buildings to be protected since the neighbourhood was listed as a historical monument in 1958, a measure to stop the demolition of the entire complex [43]. 
It is no coincidence that, compared to the rest of his facets, Le Corbusier's architectural dimension has transcended the most. This fact is more than evident with the analysis of the two main research databases: Web of Science Core Collection and SCOPUS. Respectively, 719 and 302 documents include "Corbusier" in their title. Of these, only 21 and 14 papers include the term "urban". Most of them refer to a special issue of the Journal of Architecture and Urbanism [44] or to the International Congress "Le Corbusier, 50 Years Later" [45]. This under-representation of the urban dimension of the author is also latent on the website of the Fondation Le Corbusier [5]. This is the main archive of his legacy and a key source in the study of his work. The four blocks into which all his activity is organised do not explicitly include his facet as an urban planner, which is diluted in his architectural production as a whole.

It should be noted that these data do not cast doubt on the importance of his urban planning work for the development of urban models in the 20th-century, but they do point out the fact that the study of Le Corbusier's urban planning work still has a long way to go in scientific circles. Among other reasons, it should be noted that, except in the case of Chandigarh, his urban projects did not go beyond the theoretical level. One could also point to the controversy surrounding the Athens Charter of 1933 and, by association, his early urban models [46]. However, there is one undoubted fact: the volume of his architectural production, both theoretical and practical, is much higher than the rest of the author's fields of work.

\section{Le Corbusier's Urbanism and Its Heritage Process: The Case of Chandigarh}

\subsection{An Approach to Le Corbusier's Urbanism}

The conceptual evolution of Le Corbusier's architecture and urbanism is evident. The overcoming of his early pure-machinery stage was clear from the beginning of the 1930's onwards [47] (p. 30). The differences between the early stage, which he seems to have overcome and to which relate his most novice convictions [48] (p. 104), and the stage following WWII are evident in the comparison between the Plan Voisin and Chandigarh's proposal. The second would be conceived much more as a place than a machine for living in [47] (p. 104). Nevertheless, such conceptual change would happen before. The urban plans of Amberes, L'Oued-Ouchaia, Nemours and Zlin, all from the early 1930's, show how Le Corbusier's initial city is disintegrated [47] (p. 35).

Despite this dichotomy, it should be pointed that Le Corbusier would look to the past, learning from classic antiquity and traditional architecture, throughout his all career. A testimony of his learnings while travelling East [9] would be seen in the design of public spaces during his second urban phase, with connections to Greek and Latin conceptions of public space [12]. Some echo of the past would be present in Le Corbusier's works even in his initial stage. The Immeubles Villas that comprise the outer ring of Ville Contemporaine would be inspired by Carthusian monasteries [49]. Likewise, it could be argued that Classic Antiquity would influence vanguards [50] by the understanding and application of pure geometrical forms in a manner akin to Greek and Roman models. Those would be present not only in Le Corbusier's works, but also in those of Modern Movement masters Frank Lloyd Wright, Mies van der Rohe, Alvar Aalto, or Louis Kahn [50]. In Le Corbusier's case, it is important to point out in the context of this research that besides Classical influence, he would analyse, learn and apply traditional Mughal architecture in his works [10,11].

Regarding exclusively the urban sphere, the most common references to Le Corbusier's projects are of his two earliest models: the Ville Contemporaine model, his first theoretical proposal that would only really be applied in the previously mentioned Paris Plan of 1925 [51] (p. 168), and the Ville Radieuse model, related to the former and that could be understood almost as a derivative version of the Ville Contemporaine model [51], applied to several urban plans of his earlier stage prior to WWII. Le Corbusier's first stage is usually the most studied by historiography and specialised critics, which is why, along with the Voisin Plan for Paris, the first urban models developed by Le Corbusier are the ones having the greatest prominence. 
The Ville Radieuse would be configured as an articulation of parts [52] as opposed to what was built in Paris. In Paris, the composition tended towards the concentration of uses, and the major road axes are conceived more as a support for connectivity than as linear anchors of use [3].

Therefore, the heterogeneity of Le Corbusier's complete work would be diluted if the study of his urban plans is limited to the initial part of his work, approached partially and, on occasions, erroneously extended to all his 20th-century production.

It is of interest, nonetheless, to relate these plans with those published and explained in his book The Three Human Establishments [53], where he develops the model of the Industrial Linear City, applied to encompass the aforementioned three establishments; and the model of the 7V Rule.

After these first two Cartesian, rational models of concrete morphology, there is a third model; the Rule of the 7Vs. This theoretical model was proposed in 1948 for UNESCO [53] (p. 44). This model is characterised by a series of guidelines based on seven roads, which would later become eight with the inclusion of the bicycle lane, and by presenting a less constrained and more undefined aspect than the previous models. It would be applied in Master Plans for cities such as Bogota, Marseille, and Chandigarh, the latter being the only built case.

In this sense, Carles Martí Arís [54] (pp. 18-19) defines the passage between the second model, Ville Radieuse, and the third, the Rule of the 7Vs, as a crucial turning point in the city proposed by Le Corbusier, considering the later a peak in terms of maturity, as it incorporates into the proposals the historical or geographical urban fragments that make up the cities under intervention.

The global view of these different models (Figure 4) shows the evolution in Le Corbusier's understanding of the modern city. The two earlier models disclose a greater regularity, a more significant definition of forms, orthogonality, and regularity. They are closer to rationalism and functionalism than the latter, in which forms would be more free and undefined, and could give each case a greater adaptability.

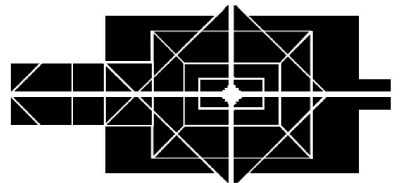

Ville Contemporaine

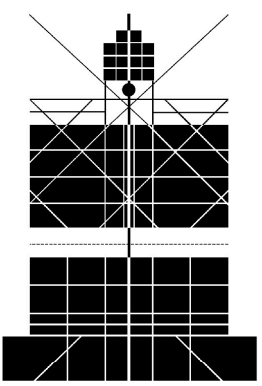

Ville Radieuse

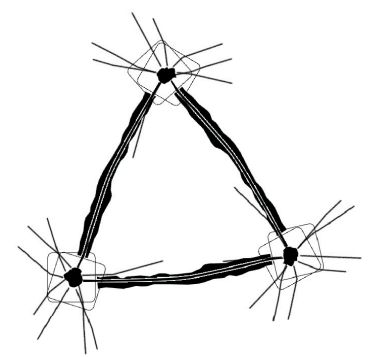

Industrial Linear City The 3 Human Settlements

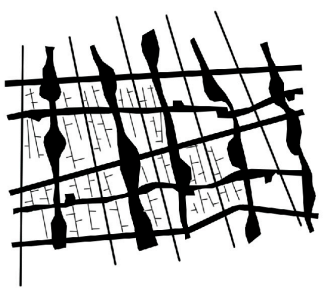

$7 \mathrm{~V}$ model

Figure 4. Le Corbusier's urban models. Source: Authors.

However, Le Corbusier's proposals were also looking to the models from before his time, those which tried to answer the problems raised from the first industrial revolution city and its salubrity issues. There can be found clear references to Howard's Garden City. This model, other than some noteworthy English examples as Letchworth or Welwyn, had been wrongly used in what can be called the garden suburbs. Besides the typologies of public space and housing that created the garden suburbs, the model of a self-sufficient city imagined by Howard would not be the one used in urban expansions. The large distances and disconnection between the suburbs and the main centres, with the consequent need for hefty commutes, would lead Le Corbusier to draw a dense garden city, with apartment buildings and stronger connexion with the original city. His two earliest models were prompted by the need for density while providing the city with garden spaces. 
In his next proposal of the Industrial Linear City is evident that he learned from Arturo Soria's Linear City. From that model, Le Corbusier not only takes the linear form, but also the idea of a city inside a given territory, as the connector between previously isolated urban settlements. The city structured in an axis would serve as an extension of the original city, more functional than the concentric ring-shaped additions to the historic centre.

Another constant in Le Corbusier's works was the concern regarding the separation between walking and driving lanes. Far from prioritising vehicle mobility in terms of allocated surface [55], Le Corbusier envisioned social spaces without motorised vehicles: "Nous avons donné tout le sol de la ville au piéton, sur la terre même: gazons, arbres, terrains de jeu: à peu près 100\% du sol à l'usage de l'habitant. [ ... ] J'ajoute: jamais un piéton ne rencontre une voiture, jamais!" [56] (p. 108). In his first models, he advocates for a three-dimensional city, with different levels and layers according to use. This way, the vehicle lanes would be at a different height than that of pedestrian green spaces, avoiding the contact between car and pedestrian, a constant of the industrialised city that Le Corbusier rejected. As an evolution of this theme, in the model of the 7Vs (V for vie, lane), he would define the seven types of V's, or lanes, according to their user and function. He would assign lanes for exclusive vehicle uses, lanes for mixed use of vehicles and pedestrians, and lanes exclusive for people's mobility. He keeps the concern of differentiating spaces according to their use, and he does so using levels and different heights for each.

Le Corbusier rejects the theme of the corridor-street, as an inheritance from the Industrial City, due to the coexisting of cars and pedestrians inside a limited space as this type of street which kept the dimensions of the historic city before the emergence of motorised vehicles.

In this sense, the first model of the Ville Contemporaine still contains the areas made up by Immeubles Villas designed with corridor-streets, although dimensioned as wide avenues. Nevertheless, Le Corbusier's second urban model, Ville Radieuse, completely rejects this public space typology. The building would disconnect from the corridor-street and from the road system, adjusting their orientation to factors as solar incidence or system of views. After WWII, Le Corbusier would recover the corridor-street but with a particular condition: those were to be the streets allocated to business and trade activities and they would make up for only a part of the proposals. It would be especially clear in the Director Plan of Bogotá and the case of Chandigarh.

Regarding zoning, the first urban models would define the areas allocated to each use with greater precision, such zoning becoming more diffuse in the 7V model. In any scenario, nonetheless, the mixing of housing with health and education facilities and leisure spaces would be a constant in Le Corbusier's trajectory. Despite applying zoning to industrial areas, the use of this tool was to provide vicinity and avoid unnecessary commutes to inhabitants, themes that would be present in all Le Corbusier's theoretical urban conceptions, from the very beginning.

Focusing on his city's proposals throughout his career, there can be seen an evolution in the urban models and their ideals, especially in the adaptability of said models to the previously existent city of its surroundings. It proves that Le Corbusier's models were guidelines or concepts to be adapted and attend to the conditions of each place, though maintaining the main lines and characteristics of the proposals.

Before the arrival of Le Corbusier in the international panorama with his firm stake for modern urbanism, though the presentation of his first urban model la Ville Contemporaine pour 3 millions d'habitants in 1922, a young Charles-Édouard Jeanneret had already proposed some designs for small urban areas with single houses, close to the low-density model of the Garden City. Of these designs, the one that made it further-although without coming to complete materialisation-was the project of Cité ouvriere in Saint-Nicolas-d'Aliermont, 1917 [57], an experimental ensemble of quality housing for the working class, of which only two terraced houses were built.

The difficulties in the construction of his urban proposals would be recurrent throughout his career. Considering the Plan Voisin for Paris of 1925, his first large-scale plan, the 
following urban plans would make a group of over twenty cases. Le Corbusier would, alongside other urban planners in most cases, design proposals for cities, such as Algiers, Barcelona, Geneva, Stockholm, Antwerp, Ghazaouet, Zlin, Hellocourt, Buenos Aires, Saint-Dié, Saint-Gaudens, La Rochelle-Pallice, Marseille, Izmir, Bogota, Meaux, Berlin and Chandigarh. Furthermore, without considering his early-career drafts for American cities such as Montevideo, São Paulo, Rio de Janeiro, and New York, even for Rome, Moscow and Addis Ababa.

Of all this bulk, the only proposal built would be the city of Chandigarh, a moment of full maturity of the French-Swiss urbanist, and the reason why this research focuses on that study case. However, not only because it was the only built city designed by Le Corbusier with an intrinsic value of authorship but also because Chandigarh is a city where a synthesis of Corbusierian models is applied, with concepts and characteristics that make it different from other modern cities closer to the Athens Charter, as Brasilia could be regarded.

\subsection{Chandigarh's Master Plan and Its Current State}

One of the main characteristics of Chandigarh, regarding Le Corbusier's urban models, is the direct use of the $7 \mathrm{~V}$ model. Its use is shown in the configuration of the different roads and lanes of the city and the creation of self-sufficient sectors. Nevertheless, in the Chandigarh Plan, some Corbusierian characteristics recall his earlier urban models, where areas were differentiated between eminently institutional spaces and housing areas.

In the Corbusierian city, the symbolic value is especially relevant. To Le Corbusier, the new civil power governing after independence could only be represented by architecture. That would also be a constant in Le Corbusier's urban projects over pre-existing cities, where he usually planted an element akin to a civic centre. Those civic centres would give the urban space a symbolic significance; the same way castles did so for feudal power, churches and cathedrals for religious power or towers for the civil 20th-century power [58] (p. 163). Thus, Chandigarh is given the Capitol complex as the representative and symbolic public space of the city. The monumental character of the Capitol recalls the main public spaces of classic antiquity.

Moreover, the sizeable green ring surrounding the ex-novo city represents a clear connection with Howard's Garden City of the early 20th century, aiming to avoid uncontrolled and unlimited city growth.

The city planned by Le Corbusier had several characteristics and a defined size which have been obliterated nowadays (Figure 5). At present, Chandigarh's municipality is almost wholly urbanised, and two satellite towns have emerged around Chandigarh. They are today perceived as one functional unity known as Chandigarh Tricity [59]. The urban trident groups Chandigarh with Mohali in the southwest and Panchkula in the southeast. Both new towns would encompass Chandigarh's urban concepts in their development, especially the use of sectors. Mohali can be understood almost as an extension of the mimetic geometry of Chandigarh, while Panchkula adds a curvilinear geometry to the design of sectors, still used as units of growth.

In its beginnings, the Chandigarh Master Plan was made of 26 sectors (FLC05104, FLC05194, FLC05201, FLC05553). It also planned a margin for growth towards the southeast and southwest with some extra 30 sectors, besides the industrial area next to the Sukhna Lake. Nowadays, Chandigarh's area encompasses 56 urbanised sectors which, according to the Master Plan, should be surrounded by a green ring. That is, alas, the space where Mohali town was developed. Mohali can be understood, in a functional level, as an expansion of Chandigarh of 127 sectors, although the sectors become more undefined and lose the relation to the road guidelines the more westward and southward they expand. In the western areas, the limits of the sectors blur with the city of Kharar. Panchkula is made of around 30 sectors, which are numbered independently from Chandigarh. Even though the fact the amount of occupied soil around Chandigarh has largely surpassed the Master Plan's proposals for west, south and east expansions, there are still new settlements 
arising around the Tricity of Chandigarh. The main is New Chandigarh, an expansion to the north and that is today under development. It was conceived as an eco-city using the same organisation in sectors and with a predominance of green spaces.

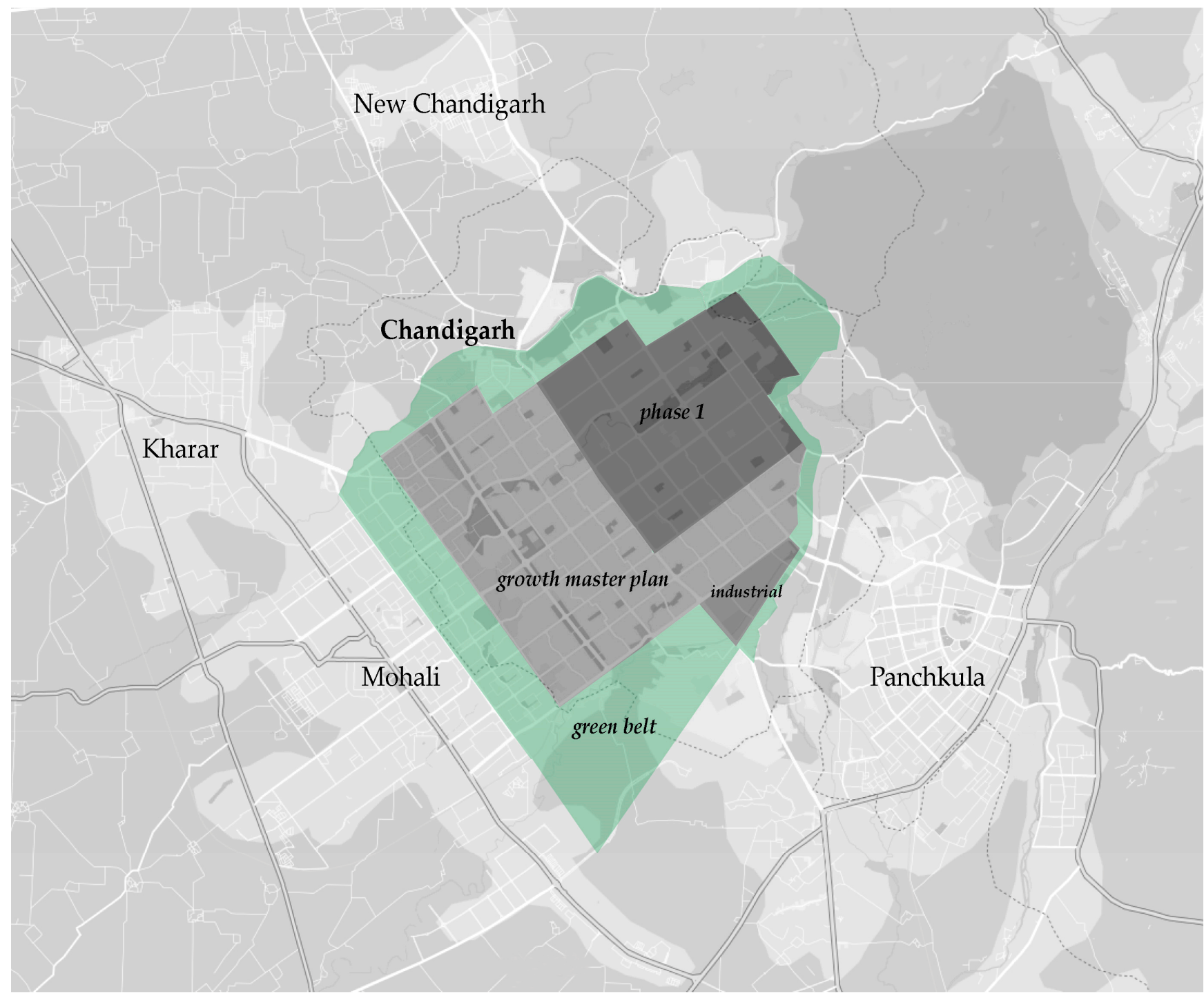

Figure 5. Chandigarh Master Plan on the current city. Source: Authors based on a map from Google Maps.

\subsection{Chandigarh and the World Heritage List}

Given the Modern Movement cities included in UNESCO World Heritage List, it is striking how Chandigarh is not yet listed especially considering that the Chandigarh Capitol ensemble has already been classified. Manish Chalana and Tyler S. Sprague [60] have compiled all efforts made to date to achieve Chandigarh's inscription. It is noteworthy that this compilation is one of the few bibliographical references regarding the heritage listing of Le Corbusier's work. When reviewing Chandigarh's listing attempts timeline, it almost made the list on several occasions. The first time, Chandigarh was included in the Tentative World Heritage List in 2006 [60] (p. 199), but five years later the Chandigarh territorial administration decided not to move the process forward [60] (p. 199). The origin of this action could be found years earlier, in 1999, with the attempt to include the Capitol complex on the List. This request was made by professionals at a conference coinciding with Chandigarh's jubilee year [60] (p. 202). 
As part of the candidacy of the Capitol ensemble, UNESCO would host in 2007 an international workshop on the management of 20th century urban landscape in Chandigarh [61]. This event was organised by UNESCO World Heritage Centre and its regional office in Delhi, in collaboration with the Chandigarh Administration, the Archaeological Survey of India (ASI) and with the support of the France-UNESCO Cooperation Agreement, supported by the Ministry of Culture and the Netherlands Funds-in-Trust. It would be conceived as a continuation of previous encounters in cities developed under urban concepts and modern language. Through the analysis of Le Corbusier's material, the participants noted that Chandigarh fitted the international standards for HUL, the UNESCO Recommendation on the Historic Urban Landscape. Moreover, they highlighted the importance to consider the intangible qualities and values of each culture and city [61].

The first steps in the listing process included urban areas of Chandigarh beyond what was grouped in the final process, as it was sought to include the city's areas that responded to the original Master Plan of Le Corbusier and his team. The modifications or interventions that distorted the initial plans, such as the green belt around the city, raised controversy about the criteria of authenticity and integrity.

In addition to the above, there are several issues around the unsuccessful attempts to get Chandigarh on the World Heritage List.

Firstly, outside specialised spheres, and given India's centuries-old and millenary heritage, Chandigarh is considered a modern city with no historical value. Moreover, safeguarding might contradict the aforementioned modern values. Anyhow, there are opposing positions that advocate safeguarding Chandigarh precisely because of the symbolic value of global and humanitarian awareness that the Indian city represents from the time of its conception, which is in line with UNESCO values [60] (p. 202).

Secondly, there are bureaucratic problems with the candidacy, which should be ratified not only by the territorial administration but also by the states of Punjab and Haryana [60] (p. 205). The delay in securing these endorsements led to a lag in the estimated deadline for submission. However, this was not the only difficulty encountered, as design and planning elites were reluctant to recognise Chandigarh as the sole work of Le Corbusier, as it would ignore the participation of several other architects and planners [60] (p. 205).

Other candidacies would be submitted later. In 2008, a transnational candidacy of a bulk of Le Corbusier's architectonic works without Chandigarh was rejected [60] (p. 205). At the same time, Chandigarh applied alone but was unsuccessful because it did not meet the application deadlines [60] (p. 206). The aforementioned transnational bid would try again in 2011, once more excluding Chandigarh from the group of works to be listed, and again it received a rejection [60] (p. 206).

Manish Chalana and Tyler S. Sprague emphasise the relevance of the recognition and the group effort of the European and Indian architecture teams, as well as Pierre Jeanneret, Jane Drew and Maxwell Fry [60]. They also point to certain parallels between the earlier Chandigarh plan of the US team of Mayer and Nowicki.

However, this work lacks, to date, a heritage approach from the analysis of urbanistic values, based on the urban model applied by Le Corbusier and its relationship with the set of theories developed throughout his career. Above all, this value judgement should highlight aspects of the project that are far removed from the generalised ideas that have transcended Le Corbusier's urban work. The generalised approach tends to centre mainly on the Voisin Plan for Paris of 1925 and the initial urban models, even though Corbusier's urbanistic production has evolved and is much richer and more diverse [55].

\subsection{Chandigarh's Urban Values}

As explained above, the overcoming of the monumentalist vision and the historicalartistic value as the paradigm of heritage has meant an opening up in the concept of heritage, favouring the incorporation of other elements as cultural assets. Consequently, there are currently various types of values that have been defined to recognise and determine heritage. Publications such as the previously mentioned Madrid Document of the 
ISC20C [25] (p. 3) determine the values of location, design, construction, facilities, social, scientific or use to list heritage.

This research is positioned in favour of the recognition and conceptualisation of global heritage understood as Cultural Heritage, taking in cultural assets of the most diverse nature. It accepts the transdisciplinarity that has been progressively configured around heritage action. However, and given the diversity of values currently configured, it is considered appropriate to identify values that have arisen from the discipline of urban planning. This aims to identify the particularity of urban interventions of the Modern Movement, based on characteristics intrinsic to it and which advocate its heritage listing. One way to advance in this task is to consider the specific case of Le Corbusier, given his international projection and influence during the 20th-century.

Focusing on the Chandigarh Master Plan, there can be seen urban planning characteristics that must be incorporated into the value judgement that accompanies any heritage process. One issue that stands out is the definition of the roads resultant from the applied model, where Le Corbusier recovers the corridor road, which he initially rejected. That rejection was due to the problems presented by this type of public space in the cities of the 19th-century. The corridor road would be mainly dedicated to motor vehicles, without having quality public spaces serving pedestrians, a model that Le Corbusier rejected as he understood that green spaces exclusive for pedestrians were essential in the city of the 20th-century. The pedestrian is at the centre of all Le Corbusier's approaches and urban production, and he dedicates large urban surfaces as public space for the use and enjoyment of the pedestrian [55]. In that sense, Le Corbusier's corridor street has a particularity, as he understands it as the appropriate typology for eminently commercial streets. In the main plan of Chandigarh (FLC05553), it can be seen how the street and its attached shops and businesses spread towards the four cardinal points.

However, if there is one particularly noteworthy feature, it is that the city is based on sectors that are conceived as self-sufficient. This is of great importance, as many of the issues addressed are still relevant today. It relates to the mix of uses, of overcoming the zoning characteristic of many of our cities and cities' expansions of the 20th-century. This mix of uses and self-sufficiency leads to a reduced need for population's mobility, and it makes the city more sustainable and habitable. There are issues of particular interest today that were already present in Le Corbusier's urban planning, such as the 15-min city.

Regarding the search for a city of proximity, in Paris, Le Corbusier's laboratory of theoretical experimentation, the project Le Paris $d u$ 1/4 heure, led by the urban planner Carlos Moreno was recently presented [62]. In relation to this theme and concerning the postCovid city, Richard Sennett [63] points out the pertinence of the revision of architecture and the city of density, as well as the concentration of activities as a challenge for urban planners today. Along the same lines as Sennett, existing neighbourhoods are being researched and analysed to test the feasibility of transforming them into 15-minute cities [64].

These concepts are found in numerous plans by Le Corbusier, as in the case of SaintDié, among others, where " $1 / 4$ d'heure de marche a pied" is written next to the graphic scale, sometimes next to a pedestrian walking [3].

In Chandigarh's case, the planimetry of the Master Plan shows a graphic scale that includes a pedestrian and the subtitle "QUARTER HOURS WALK" under the $\frac{3}{4}$ mile (Figure 6).

This understanding of the commuter city is present in Chandigarh, where the selfsufficient sectors are approximately $800 \times 1500 \mathrm{~m}$ in size in most cases, except sectors two to six, the ones closer to the Capitol, which are smaller at $350 \times 750 \mathrm{~m}$. Each sector would be dotted with pedestrian-only green public space where educational buildings of various grades, health centres, community centres, swimming pools and shopping streets are in the vicinity (FLC05553) (Figure 7). In this way, it seeks the complexity of use and rejects highly specialised sectors, except for the industrial sector. 


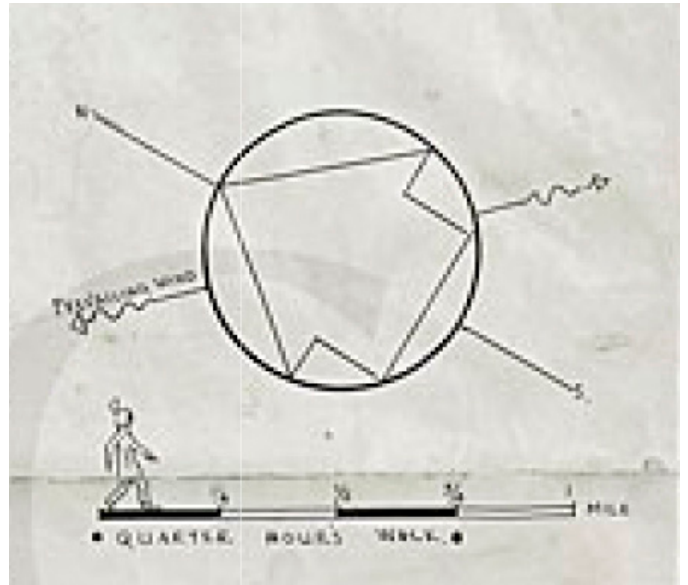

Figure 6. Representation of the quarter-hour on foot on the graphic scale. Extract from the FLC05104. Source: (C) FLC/ADAGP.

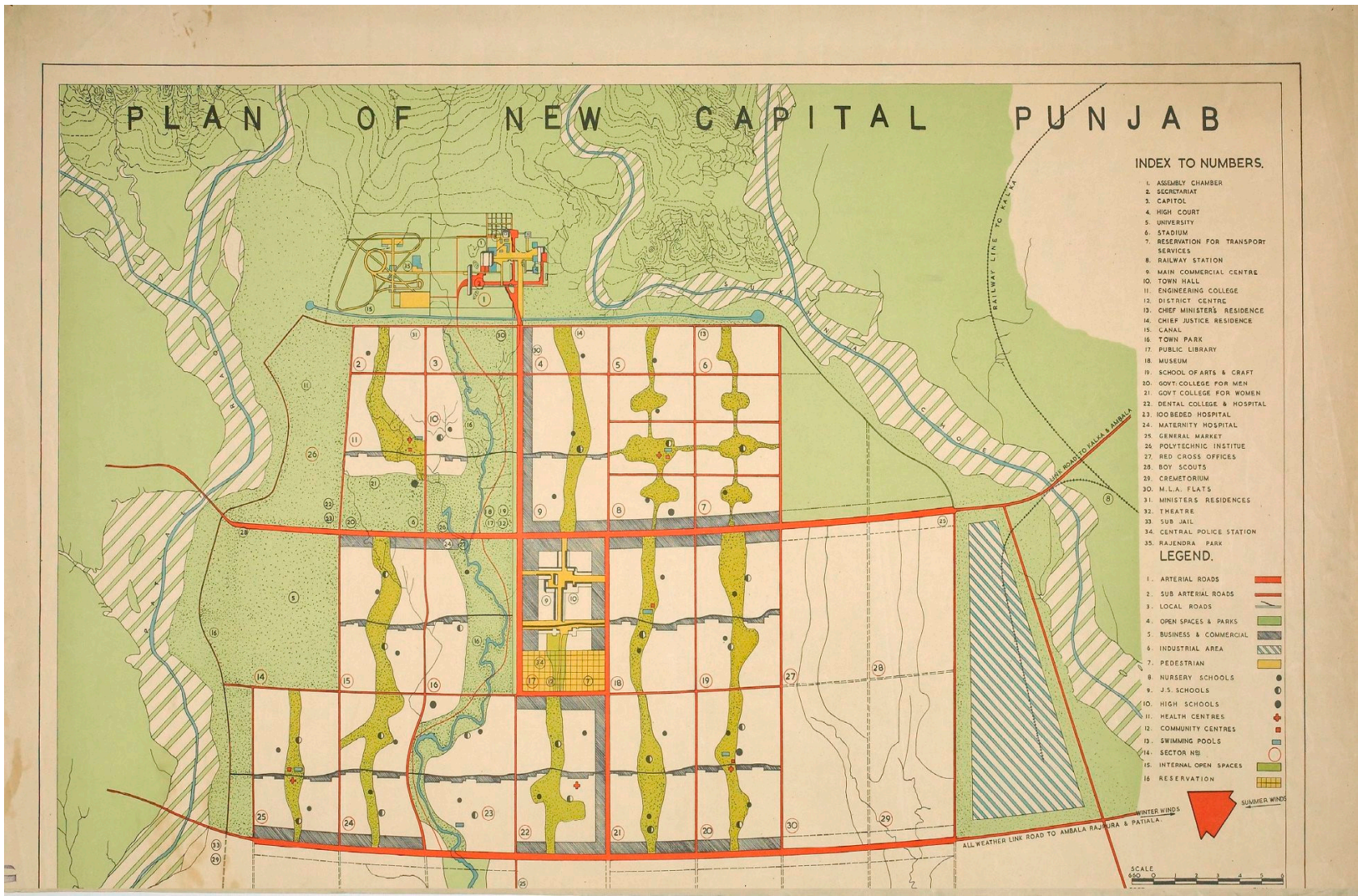

Figure 7. Chandigarh's Master Plan. FLC05553. Source: @ FLC/ADAGP.

All those factors were envisaged in the Master Plan, and, with greater or lesser detail, they were implemented in the current city. The global analysis of the different sectors that build Chandigarh shows the mixing of uses intended by Le Corbusier and his team. The sectorial analysis and the plans for each sector are made available by the Chandigarh administration [65].

In the middle of the sectors, there can be found today education centres of different levels, cinemas, theatres, health centres, social clubs, police stations, museums, and veterinary services, among other facilities that make sectors complex entities of services. Services are located in the linear public spaces (streets) that run through the sectors. The time to walk 
through each sector, considering their size, is estimated at $15 \mathrm{~min}$. However, that would not be possible in the trips to the Capitol complex, as its location on the northern extreme of the city would make the distance to the southern sectors more than $1 \mathrm{k}$. Nevertheless, except for civil servants working in the Capitol, they are not of everyday use and the normal daily life of the majority of Chandigarh's inhabitants is solved inside the space of a 1 kilometre radius (Figure 8). The green areas are closely connected to construction areas, creating connection spaces between services and housing.

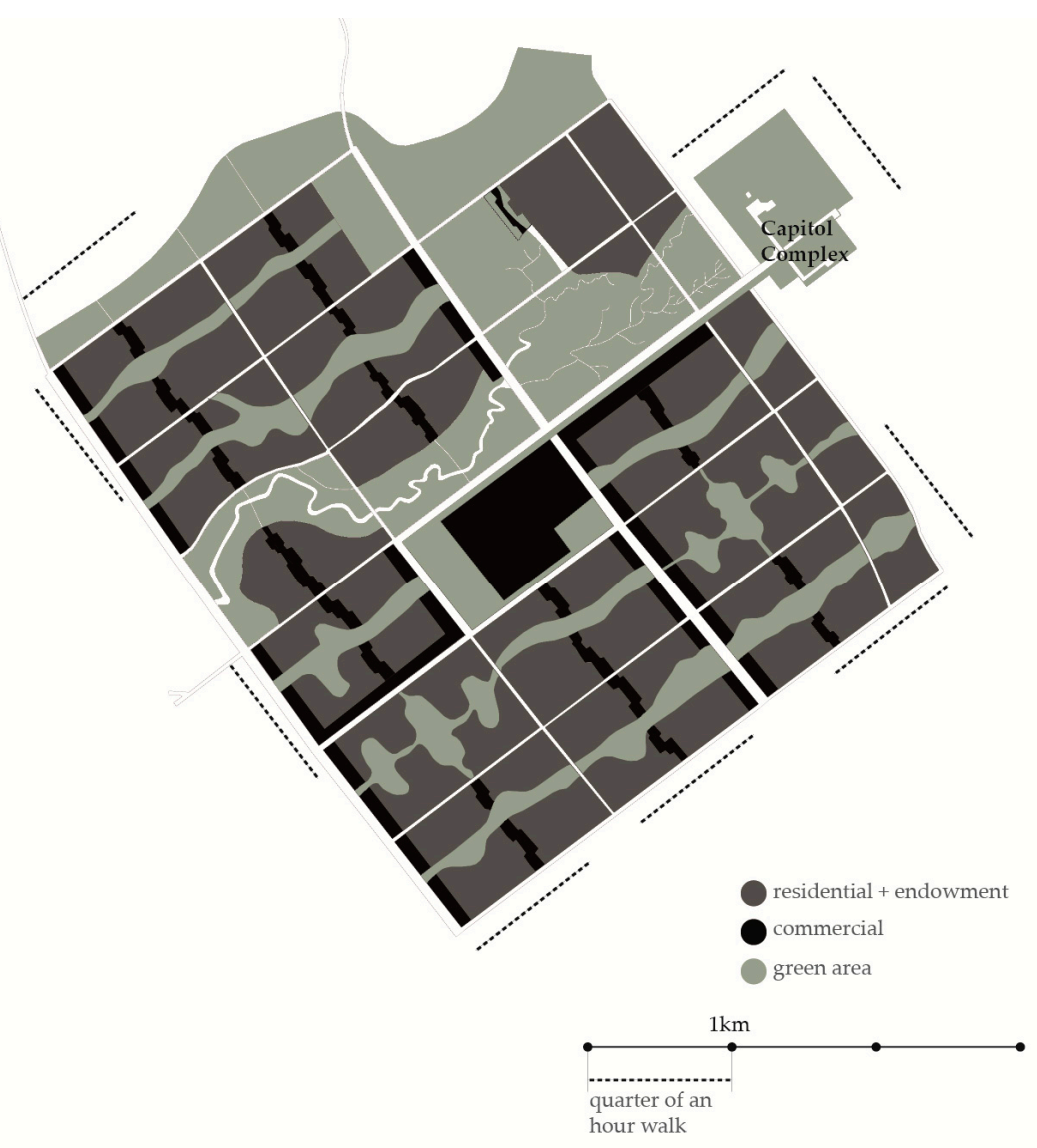

Figure 8. Quarter of an hour walk analysis of Chandigarh Master Plan. Source: Authors.

Besides pedestrian mobility, the Master Plan proposed a bus network (FLC05277, FLC05286) to connect the whole city with public transportation.

\section{Towards the Heritage Recognition and Protection of Chandigarh}

The urban projects of the 20th century present a series of difficulties for their heritage recognition and, therefore, their legal protection. The first issue has to do with their age. Devoid of the subjective character with which Riegl [66] (p. 31) defines the value of antiquity, historical value has become a consolidated source of authority on which the protection of urban heritage has been based [67] (p. 7). However, this is still one of the main handicaps of contemporary heritage [68] (p. 77). Despite the progress made, estimating the significance of urban design from such a recent period remains a difficult task given the need to establish a clear historical context [69] (p. 7).

Moreover, the urban developments of the 20th century are the moment of more significant growth of the cities and, therefore, the moment of greatest urban planning in their recent urban history. It is difficult to apply criteria of representativeness and singularity to a legacy that is characterised by its Fordian aspiration for massive, standardised and certainly homogeneous urban production. This rapid growth can also lead to an absence of a sense of community, of identity and, above all, of rootedness in the history of a newly created 
place [70] (p. 11). Furthermore, many cases have undergone significant alterations from the first ideas that sought to meet changing needs and new standards, which undermine the values of authenticity and integrity that could have articulated their cultural significance.

The recognition of contemporary heritage has not abandoned the outdated double condition of historical and artistic value [13] (p. 81). Even today, its protection is still based on mainly object-related considerations as its formal characteristics and thus is closer to an approach to heritage from the monumentalist viewpoint of the last century [71] (p. 404).

This is the reason why until now, in Chandigarh, interest has concentrated on certain institutional buildings, while the areas intended to house the local population-devoid of any hint of exceptionality insofar as they are associated with everyday life-lack any kind of heritage recognition.

Despite these considerations, the analysis of the case study allows us to affirm that urban construction presents a series of potentialities that can ground the necessary value judgement to overcome these weaknesses.

To understand the modern city as a material and cultural expression of the 20thcentury, in terms of the Amsterdam Charter (1975) [72], is to resort to the already consolidated historical value in the protection of the historic city, which inexorably leads to the recognition of these pieces. They tell the specific background of each context, as well as favouring cultural and heritage diversity, as defended by the Nara Document on Authenticity (1994) [73].

In this sense, the plan for Chandigarh stands out as a proposal that differs from so many others in Le Corbusier's career. It presents a characterisation and pattern that would not be repeated in any of his urban projects, at least projects of inland cities [55] (pp. 10-11). That singularity must be recognised as the result of the theoretical evolution experienced throughout his career.

A historical approach to the 20th-century city means the recognition of the recommendation on historic urban landscape [74], which defines the city as "the urban area resulting from a historical layering of cultural and natural values and attributes, which transcends the notion of the historic ensemble or centre to encompass the general urban context and its geographical setting".

The urban functionalities of the 20th-century city were designed to satisfy very specific needs, for example, the compatibility of institutional and residential use in the case of Chandigarh. This adds to them some values: use-value, assumed as a criterion for assessing the conservation effort in addition to cultural value [72], and functional-value, as the continuity of the original functions reinforces their significance, which cannot be achieved through interpretative manifestations [75] (p. 5).

There is yet another dimension, of an immaterial nature, that can be assigned to usevalue, which is the increase in knowledge [76] (p. 68). This is particularly relevant in the case of Le Corbusier's set of urban planning projects, even if not executed. If it is assumed that tutelary action today transcends the sphere of protection exclusively and is defined by a circular process of interaction between different historical phases, the recognition of values, the constitution of a new legal context, the actions of intervention and how these values are disseminated, it can only be articulated based on solid and necessary research that allows us to establish appropriate value judgements.

In the specific case of Chandigarh, as Le Corbusier's only built urban proposal, this value of immaterial use can be associated with the specific knowledge of how the ideas of city modernity have been adapted to the national and local context of each case. Moreover, it allows for an analysis of its evolution and the study of positive and negative key factors, so to advance in the construction and evolution of future urban plans. Not only is it a process rooted in the past, but the existence of research and studies on these urban projects means an accumulation of value in knowledge.

The presence, total or partial, of concepts of present-day urban planning in Le Corbusier's work and, especially, in the Chandigarh Master Plan, justifies not only the pertinence of its revision but also its safeguard, as the only built example of the Corbusierian urban 
planning legacy and, ultimately, of the ideals of 20th-century urban planning applied on the ground.

Chandigarh, like many other urban developments of the 20th-century, is the canvas of a broad social fabric. The modern city holds values "related to the emotional bonds of society [ ... ] which have a strong impact on its safeguarding, conservation and restoration" [75] (p. 4). It ties the population residing in these dwellings and helps in the recognition of their identity as a whole, not only by themselves but also by the remaining local population.

This social value plays an important role in establishing the social and cultural identity of the resident population. It will condition the interaction between its residents, and what is of greatest heritage interest, will generate in them an essential feeling of belonging to the place and to the collective that inhabits it. Therefore, any intervention will be determined by the fact that residents are happy with the city where they live [77] (p. 47).

Even if it is not true in all cases, this feeling of belonging is directly associated with interest and concern for the state of conservation, motivating its maintenance and rehabilitation. A capacity that today is encompassed within the meanings of the term 'resilience' and that, applied to the urban sphere, can be translated into the self-organising capacity as a collective [78].

\section{Discussion \& Conclusions}

As evidenced throughout this article, the evolution of the concept of heritage shows the relevance of considering the recognition and protection of the heritage of modern urban proposals. The review of 20th century international documents shows the opening up of the concept beyond the monumentalist vision and the overcoming of the temporary historical value as a unique and essential characteristic when it comes to assessing the cultural legacy to be preserved. This casuistry has led Modern Movement architecture and urbanism to be included in the concept of heritage, given the concern that arose from the loss of masterpieces of this period. Numerous advances have been made since before the end of the 20th century. The inclusion of buildings from the Modern Movement and, to a lesser extent, of urban entities on UNESCO's World Heritage List demonstrates the evolution experienced in international forums specialising in heritage matters. It reaffirms the relevance of attending to this heritage.

However, despite the progress made today, the urban scale is still characterised by a low level of heritage consideration. It should be borne in mind that urban planning, as with architecture, reflects an era, of a specific way of living, according to the needs and theories of the time. For these reasons, the uniqueness of modern urban planning, which draws on urban concepts from the past, should be a legacy to be preserved for future generations.

Focusing on the work of Le Corbusier, it is worth noting how, of all his built work, only approximately $58 \%$ is under heritage protection, with the cases of France and Switzerland standing out. In contrast, India, the country with the second-largest number of Le Corbusier's buildings after France, is notable for not having any of its 19 buildings protected, not even those included on the World Heritage List. In this sense, and given the eight buildings demolished out of the three not protected, it is pertinent to highlight the importance of this safeguard to avoid further losses.

Le Corbusier's urbanistic facet is researched and represented to a lesser extent than his architectural facet. Among other factors, because of the Athens Charter's controversies, his first models or the Voisin Plan. Overcoming this partial view of a much broader and more diverse trajectory opens the way to subjects and objects of study that augur well for a remarkable scientific career.

In this regard, the conceptual evolution present in Le Corbusier's work and theory, both urbanistic and architectural, throughout his career-without forgetting the links with the past-stands out. His urban models, mainly the $7 \mathrm{Vs}$, and their application to the case of Chandigarh, could be understood as bringing together previous concepts and models, taking previous concepts, updating them to the needs of the moment, and including new 
disciplinary reflections. This fact underlines the value of this author's contributions to the evolution of contemporary urbanism and, therefore, from a heritage point of view.

The unsuccessful attempts to include Chandigarh on the World Heritage List highlight the need to move towards recognising values and heritage reading from an eminently urban perspective. It should be advocated that cultural significance assessments are drawn more closely to the scale, dimension and focus of any urban development, seeking to complement the criteria or values generally applicable to other natural heritage and historical stages-as individual buildings - with new criteria that serve the urban scale heritage.

The changes from the initial approaches and concepts of the Chandigarh Master Plan to the present city, such as the inexistence of the green belt that sought to set the city's boundaries, points to the transformations to which cities are subject regardless of their historical origin. Consequently, the loss of authenticity or integrity, criteria required by UNESCO to be listed as World Heritage, has been discussed in specialised heritage circles. However, this fact can also be interpreted in the opposite sense, in the opinion of this research. That is to say, the lack of recognition and safeguarding of elements of interest as heritage has led to their transformation and consequent loss of heritage values. Safeguarding them does not mean paralysis over time, primarily if it is understood that the continued use and adaptation of heritage assets to new needs is what makes them survive. The heritage recognition of its urban characteristics would allow that, in the event of necessary adaptations to new paradigms, any intervention is carried out under criteria that do not detract from the value of the heritage asset.

On the other hand, throughout the article, a series of eminently urbanistic values have been identified and described for the case study, going beyond the value of authorship or singularity, two criteria already consolidated in heritage practice. Chandigarh stands out for being the synthesis city of the Corbuserian models in their full maturity. It also embodies an alternative vision to the ideal modern city model, represented by Brasilia, currently inscribed on the World Heritage List. The urban growths around Chandigarh share common characteristics with Chandigarh. This fact reflects Le Corbusier's plan's influence on its immediate surroundings and inspiring many others internationally. The research has also identified concepts of undoubtedly current relevance, such as the mix of uses and the 15-minute commuter city. All of them constitute values that will allow progress to be made in their definitive heritage recognition from a holistic vision that incorporates and consolidates their urban values.

However, in cases such as Chandigarh, the social value can also be translated into the fact that it forms a shared heritage since the public administration promoted it. This can reflect particular political wills and/or events, and in the case of Chandigarh, it shows the modern spirit of the new Indian nation. In addition to their contribution to the historical value mentioned above, the ideological aspects of the city construction can condition, positively or negatively, the collective perception of the local population over these ensembles.

Be that as it may, the social vector is particularly relevant at a time when heritage management has changed from a static practice to a more dynamic one, adjustable to the development of the city and the needs of its inhabitants. New practices mean new approaches where heritage management seeks to decentralise to the local level and to involve citizens in heritage classification processes through participatory actions.

Following these reflections, the research has sought to demonstrate that the specific characteristics of 20th-century urban developments and, specifically, the case of Chandigarh, require the application of complementary criteria to those generally used in heritage protection, mainly an object-based approach. From a contemporary perspective, it is necessary to adapt both the general protection systems and the cultural value assessments from an urban approach to heritage. This advance will make it possible to take a significant step forward in the process of heritage recognition of the urban legacy of the 20th-century, with the ultimate goal of achieving higher levels of social recognition. 
Author Contributions: Conceptualisation and methodology, J.-A.R.-L. and D.N.-C.; formal analysis, investigation, resources, writing-original draft preparation, visualisation and funding acquisition, J.-A.R.-L.; writing-review, editing and supervision, J.-A.R.-L., A.R. and D.N.-C. All authors have read and agreed to the published version of the manuscript.

Funding: This research was funded by the Ministry of Science, Innovation and Universities of the Government of Spain (FPU17/03701) and supported by the University of Seville.

Conflicts of Interest: The authors declare no conflict of interest.

\section{References}

1. Calatrava, J.; Dercelles, A.; Torres Cueco, J. Editorial. LC. Rev. Rech. Corbusier 2020, 1, 4-8. [CrossRef]

2. UNESCO. The Architectural Work of Le Corbusier, an Outstanding Contribution to the Modern Movement. Available online: https:/ / whc.unesco.org/en/list/1321 (accessed on 8 June 2021).

3. Rodríguez Lora, J.A. El Urbanismo de Le Corbusier. Caracterización de sus Propuestas para Ciudades de Interior. Master's Thesis, University of Seville, Seville, Spain, 2020.

4. Rodríguez-Lora, J.A.; Navas-Carrillo, D.; Pérez-Cano, M.T. Le Corbusier y las Redes Sociales. Análisis de la Difusión de su Legado Urbanístico. In Cosmovisión de la Comunicación en Redes Sociales en la era Postdigital, 1st ed.; Sierra Sánchez, J., Barrientos Báez, A., Eds.; McGrawHill: Madrid, Spain, 2021; Volume 1, pp. 635-650.

5. Fondation Le Corbusier. Available online: http://www.fondationlecorbusier.fr (accessed on 8 June 2021).

6. Fondation Le Corbusier. Le Corbusier Plans, Box 1-Box 4; Fondation Le Corbusier: Paris, France, 2005-2012.

7. Pico Valimaña, R. Arquitectura del MOVIMIENTO MODERNO y tutela patrimonial. El caso andaluz. In IAPH. Cuadernos. La Arquitectura Moderna en Andalucía: Un Patrimonio por Documentar y Conservar. La Experiencia DOCOMOMO; Consejería de Cultura de la Junta de Andalucía, Instituto Andaluz de Patrimonio Histórico: Seville, Spain, 1999; pp. 18-25.

8. De Jonge, W. Sleeping Beauty. In Designing from Heritage. Strategies for Conservation and Conversion; TU Delft-Heritage and Architecture: Delft, The Netherlands, 2017; pp. 14-29.

9. Daza Caicedo, R. Tras el Viaje de Oriente. Charles-Édouard Jeanneret_Le Corbusier; Fundación Arquia: Barcelona, Spain, 2015.

10. Quintana Guerrero, I.; O’Byrne Orozco, M.C. The void in Chandigarh's Capitol Complex: A legacy at an Eastern scale. LC. Rev. Rech. Corbusier 2021, 3, 28-41. [CrossRef]

11. Jahnkassim, P.S.; Nawawi, N.M. Allusions to mughal urban forms in the monumentality of Chandigarh's Capitol Complex. J. Archit. Urban. 2016, 40, 177-190. [CrossRef]

12. Sequeira, M. Towards a Public Space. Le Corbusier and the Greco-Latin Tradition in the Modern City; Routledge: London, UK, 2017.

13. Capitel, A. Notas sobre la identidad y la protección de los bienes patrimoniales modernos. In Criterios de Intervención en el Patrimonio Arquitectónico del Siglo XX, Proceedings of the Conferencia Internacional CAH20thC; Documento de Madrid 2011; Ministerio de Cultura, Secretaría General Técnica-Subdirección General de Publicaciones, Información y Documentación: Madrid, Spain, 2011.

14. Flores López, C. Arquitectura Española Contemporánea, 2nd ed.; Aguilar: Madrid, Spain, 1989.

15. Pérez Escolano, V. Arquitectura MODERNA como PATRIMONIO. In IAPH. Cuadernos. La Arquitectura Moderna en Andalucía: Un Patrimonio por Documentar y Conservar. La Experiencia DOCOMOMO; Consejería de Cultura de la Junta de Andalucía, Instituto Andaluz de Patrimonio Histórico: Seville, Spain, 1999; pp. 12-17.

16. Mosquera Adell, E. Prólogo. Arquitectura sevillana: Racionalismo y vanguardia imposible. In 3G: El Espíritu de la Tercera Generación en la Arquitectura Sevillana de los Años 60; Escuela Técnica Superior de Arquitectura de Sevilla: Seville, Spain, 1996.

17. Rodríguez-Lora, J.A.; Navas-Carrillo, D.; Pérez-Cano, M.T. El patrimonio contemporáneo en la ciudad histórica de Sevilla. La protección del Movimiento Moderno (1925-1975) desde el planeamiento urbanístico. Urbe. Rev. Bras. Gestão Urbana 2021, 13, e20200153. [CrossRef]

18. CIATMH. Carta de Atenas para la Restauración de Monumentos Históricos; CIATMH: Athens, Greece, 1931.

19. UNESCO. Acta Final de la Conferencia Intergubernamental Sobre la Protección de Bienes Culturales en Caso de Conflicto Armado; UNESCO: The Hague, The Netherlands, 1954.

20. ICOMOS. Carta Internacional para la Conservación y Restauración de Monumentos y Sitios; Consejo Internacional de Monumentos y Sitios: Venice, Italy, 1964.

21. Comisión de Resolución. Declaración de Praga. In Resolución para la Protección de los Monumentos Culturales de los Siglos XIX y XX; Comisión de Resolución: Prague, Czech Republic, 1971.

22. Docomomo. Declaración de Eindhoven; Docomomo: Eindhoven, The Netherlands, 1990.

23. Comité de Ministros, Consejo de Europa. Recomendación (91) 13 del Comité de Ministros a los Estados Miembros Relativa a la Protección del Patrimonio Arquitectónico del Siglo XX; Consejo de Europa: Brussels, Belgium, 1991.

24. UNESCO. World Heritage Papers 5, Identification and Documentation of Modern Heritage; UNESCO: Paris, France, 2003.

25. International Scientific Committee-ISC20C. Criterios de Conservación del Patrimonio Arquitectónico del Siglo XX; Documento de Madrid; ISC20C: Madrid, Spain, 2011.

26. Spoormans, L.; Pereira Roders, A. Methods in assessing the values of architecture in residential neighbourhoods. Int. J. Build. Pathol. Adapt. 2021, 39, 490-506. [CrossRef] 
27. Getty Conservation Institute. Conserving Modern Architecture Initiative. Available online: https://www.getty.edu/ conservation/our_projects / field_projects / cmai/cmai_overview.html (accessed on 8 June 2021).

28. UNESCO. Rietveld Schröderhuis (Rietveld Schröder House). Available online: https://whc.unesco.org/en/list/965 (accessed on 8 June 2021).

29. UNESCO. Tugendhat Villa in Brno. Available online: https:/ / whc.unesco.org/en/list/1052 (accessed on 8 June 2021).

30. UNESCO. The 20th-Century Architecture of Frank Lloyd Wright. Available online: https://whc.unesco.org/en/list/1496 (accessed on 8 June 2021)

31. UNESCO. Bauhaus and Its Sites in Weimar, Dessau and Bernau. Available online: https://whc.unesco.org/en/list/729 (accessed on 8 June 2021).

32. UNESCO. Ciudad Universitaria de Caracas. Available online: https:/ / whc.unesco.org/en/list/986 (accessed on 8 June 2021).

33. UNESCO. Campus Central de la Ciudad Universitaria de la Universidad Nacional Autónoma de México. Available online: https:/ / whc.unesco.org/en/list/1250 (accessed on 8 June 2021).

34. UNESCO. Brasilia. Available online: https://whc.unesco.org/en/list/445 (accessed on 8 June 2021).

35. Pérez Cano, M.T.; Mosquera Adell, E. La Contemporaneidad Reconocida. Arquitectura, Ciudad y Paisaje construido en la Lista de Patrimonio Mundial: Un proceso abierto. Oculum Ens. 2016, 13, 5-27. [CrossRef]

36. UNESCO. Le Havre, the City Rebuilt by Auguste Perret. Available online: https://whc.unesco.org/en/list/1181 (accessed on 8 June 2021).

37. UNESCO. White City of Tel-Aviv-The Modern Movement. Available online: https://whc.unesco.org/en/list/1096 (accessed on 8 June 2021).

38. UNESCO. Casablanca. Ville du XXème Siècle, Carrefour D'influences. Available online: https://whc.unesco.org/en/ tentativelists /5848/ (accessed on 8 June 2021).

39. Le Corbusier. Oeuvre Complète 1910-1969; Les Éditions d'Architecture: Zurich, Switzerland, 1930-1970.

40. Ministère de la Culture. Mérimée: Une Base de Données du Patrimoine Monumental Français de la Préhistoire à nos Jours. Available online: https:/ / www.culture.gouv.fr/Espace-documentation/Bases-de-donnees/Fiches-bases-de-donnees/Merimee-une-basede-donnees-du-patrimoine-monumental-francais-de-la-Prehistoire-a-nos-jours (accessed on 5 July 2021).

41. Federal Office for Civil Protection-FOCP, Swiss Confederation. Inventaire Suisse des Biens Culturels D'importance Nationale et Régionale. Available online: https:/ / www.babs.admin.ch/fr/aufgabenbabs/kgs/inventar.html (accessed on 14 June 2021).

42. Ministry of Culture. List of State Protected Monuments. Available online: https://asi.nic.in/monuments/ (accessed on 12 June 2021).

43. Gaukel, I.; Geiger-Schmidt, E. Die Weißenhofsiedlung und die Beamtensiedlung in Stuttgart. Geschichte der Denkmalausweisung. Denkmalpfl. Baden-Württemberg Nachr. Landesdenkmalpflege 2019, 48, 206-2014. [CrossRef]

44. Sequeira, M. Rethinking Le Corbusier: Urban design and history. J. Archit. Urbanism 2016, 40, 59. [CrossRef]

45. Torres Cueco, J. Le Corbusier. 50 Years Later; Universitat Politècnica de València: Valencia, Spain, 2015.

46. National Geographic. Ideas for a Brighter Future, the Cities Issue; National Geographic Partners: Washington, DC, USA, 2019.

47. Frampton, K. El otro Le Corbusier: La forma primitiva y la ciudad lineal, 1929-1952. Arquit. Rev. Col. Of. Arquit. Madr. 1987, 264-265, 30-37.

48. Sennett, R. Construir y Habitar. Ética para la Ciudad; Anagrama: Barcelona, Spain, 2019.

49. Sequeira, M. Immeuble-villas de 1922 y las variants cartujas. In La Recherche Patiente. Le Corbusier. Cincuenta Años Después-Fifty Years Later; Torres Cueco, J., Mejía Vallejo, C.E., Eds.; TC Cuadernos, General de Ediciones de Arquitectura: Valencia, Spain, 2015; pp. 262-273.

50. Fernández Galiano, L. El Clasicismo de las Vanguardias Arquitectónicas; Fundación Amigos del Museo del Prado: Madrid, Spain, 2014-2015; Available online: https:/ / youtu.be/-SaTwyPXuWw (accessed on 5 July 2021).

51. Monteys, X. La Gran Máquina: La Ciudad en Le Corbusier; Colegio Oficial de Arquitectos de Cataluña, Demarcación de Barcelona: Barcelona, Spain, 1996.

52. Alonso Pereira, J.R. El París de Le Corbusier; Editorial Reverté: Barcelona, Spain, 2015.

53. Le Corbusier. El Urbanismo de los tres Establecimientos Humanos; Editorial Poseidón: Buenos Aires, Argentina, 1964.

54. Martí Arís, C. Le Corbusier: Bogotá, vista aérea. In Le Corbusier en Bogotá, 1947-1951; O’Byrne Orozco, M.C., Ed.; Universidad de los Andes: Bogotá, Colombia, 2008; pp. 16-19.

55. Rodríguez-Lora, J.A.; Navas-Carrillo, D.; Pérez-Cano, M.T. Le Corbusier's Urbanism: An Urban Characterisation of His Proposals for Inner Cities. Front. Archit. Res. 2021. [CrossRef]

56. Le Corbusier. La Ville Radieuse: Eléments d'une Doctrine D'urbanisme Pour L'équipement de la Civilisation Machiniste; Paris Vincent Fréal \& Cie: Paris, France, 1964.

57. VVAA. Le Corbusier Plans, Box 1; Fondation Le Corbusier: Paris, France, 2005; Volume 1.

58. Boesiger, W. Le Corbusier. Oeuvre Complète 1938-1946; Les Éditions d'Architecture: Zurich, Switzerland, 1995.

59. District Panchkula, Government of Haryana. About District. Available online: https://panchkula.nic.in/about-district/ (accessed on 5 July 2021).

60. Chalana, M.; Sprague, T.S. Beyond Le Corbusier and the modernist city: Reframing Chandigarh's 'World Heritage' legacy. Plan Perspect. 2013, 28, 199-222. [CrossRef] 
61. UNESCO. International Workshop Management of Historic Urban Landscape of the XXth Century. Available online: https: //whc.unesco.org/en/activities/762/ (accessed on 5 July 2021).

62. Moreno, C. La Covid descubre un nuevo localismo. In Todo Noticias-Tarde-RTVE Radio 5. Available online: https://www rtve.es/alacarta/audios/todo-noticias-tarde/carlos-moreno-ciudad-15-minutos-paris-localismo/5580008/ (accessed on 11 June 2021).

63. Sennett, R. Hacia Ciudades de 15 Minutos. Available online: https://elpais.com/especiales/2020/coronavirus-covid-19 /predicciones/hacia-ciudades-de-15-minutos / (accessed on 11 June 2021).

64. Córdoba Hernández, R.; Hernández Aja, A.; Fernández Ramírez, C.; Álvarez del Valle, L. Hacia la Ciudad de los 15 Minutos Frente al COVID19. La Densidad Espacial de Madrid. Available online: http://vps181.cesvima.upm.es/re-hab/2020/05/06 / hacia-la-ciudad-de-los-15-minutos-frente-al-covid19-la-densidad-espacial-de-madrid/ (accessed on 11 June 2021).

65. Chandigarh Administration. Interactive Map of Chandigarh. Available online: http://chandigarh.gov.in/knowchd_map.htm (accessed on 6 July 2021).

66. Riegl, A. Der Moderne Denkmalkultus; W. Braumüller: Viena, Austria; Prague, Czech Republic, 1903.

67. Moya, L.; Monjo, J.; Díez de Pablo, A. La arquitectura ordinaria del siglo XX como patrimonio cultural: Tres barrios de promoción oficial de Madrid. EURE Rev. Estud. Urbano Reg. 2015, 43, 15-25. [CrossRef]

68. Feilden, B. Conservation of the 20th Century Building. In Proceedings of the Seminar on 20th Century Heritage, Helsinki, Finland, 18-19 June 1995; ICOMOS: Helsinki, Finland, 1995.

69. INTI. Report International New Town Day 2018. New Town Boom Town; International New Town Institute: Roterdam, The Netherlands, 2019. Available online: http:/ / www.newtowninstitute.org/pdf/INTI-reportINTD18-screen.pdf (accessed on 12 June 2021).

70. Nagtegaal, T. Lelystad in Transformatie; Academie van Bouwkunst Amsterdam: Amsterdam, The Netherlands, 2012.

71. Mosquera Adell, E.; Pérez Cano, M.T. Refugios Conocidos. De Patrimonio de los Arquitectos a Patrimonio de Todos. In Criterios de Intervención en el Patrimonio Arquitectónico del Siglo XX; Hernández León, J.M., Espinosa de los Monteros, F., Eds.; Ministerio de Cultura: Madrid, Spain, 2011; pp. 403-410.

72. Council of Europe. European Charter for Architectural Heritage; Committee of Ministers of the Council of Europe: Amsterdam, The Netherlands, 1975.

73. ICOMOS. Nara Document on Authenticity; ICOMOS: Nara, Japan, 1994.

74. UNESCO. Recommendation on the Historic Urban Landscape; UNESCO: Paris, France, 2011.

75. UNESCO. Some Reflections on Authenticity; UNESCO: Paris, France, 2004.

76. Ballart i Hernández, J. El Patrimonio Histórico y Arqueológico: Valor y Uso; Ariel: Barcelona, Spain, 2002.

77. Zijlstra, H. Jeruzalem Amsterdam: Restaureren versus renoveren. Bull. KNOB K. Ned. Oudheidkd. Bond. 2013, 112, 34-50.

78. Meerow, S.; Newell, J.P. Urban resilience for whom, what, when, where, and why? Urban Geogr. 2019, 40, 309-329. [CrossRef] 